\title{
Aydıncık-Duruhan (Mersin) Arasının Stratigrafisi
}

\section{The Stratigraphy between of the Aydıncik and Duruhan}

\author{
Ahmet TURAN ${ }^{*}$ (D) \\ ${ }^{1}$ Konya Teknik Universitesi Mühendislik ve Doğa Bilimleri Fakültesi Jeoloji Müh. Konya/Türkiye \\ Sorumlu Yazar / Corresponding Author *: aturan@selcuk.edu.tr \\ Geliş Tarihi / Received: 10.10.2018 DOI:10.21205/deufmd.2019216226 \\ Kabul Tarihi / Accepted: 25.12.2018 Arastırma Makalesi/Research Article \\ Atıfssekli/How to cite: TURAN, A. (2019). Aydınclk-Duruhan (Mersin) Arasının Stratigrafisi. DEUFMD, 21(62), 633-647.
}

Öz

Aydıncık-Duruhan yöresinde, Aladağ Birliği veya Hadim Napına ait allokton birimler yüzeyler. İstfilenme Geç Devoniyen yașlı ve dolomit-resifal kireçtașı-kuvarsit-șeyl içerikli Asarlıkyaylası formasyonuyla başlar. Üzerine bol fosilli kireçtaşı ve kuvarsit ardışımı şeklinde Karbonifer yaşlı Yarıcak formasyonu gelir. Daha üstte Girvenella'lı, fuzulinli ve krinoidli kireçtaşından oluşmuş Erken Permiyen yaşlı Arpalık formasyonu vardır. Bir aşınım yüzeyinden sonra kuvarsit-şeyl ara tabakalı ve bol algli kireçtaşlarından oluşan Kuşakdağı formasyonu izlenir. Kuşakdağı birimni stromatolitli-oolitli karbonat yapılışlı ve Erken Triyas yaşlı Gökçepınar kireçtaşı, uyumlu olarak örter. Daha sonra bol bivalvli şeyl-marn-kireçtaşı yapılışlı, Erken-Orta Triyas yaşlı Göztaşı formasyonu izlenir. Liyas-Malm aralığında kızıl renkli çakıltașı-kumtașı-çamurtașı bileșenli Çamiçi ve alacalı renkli çamurtaşı-şeyl-killi kireçtaşı yapılışlı Dedebeleni formasyonları, geçişli olarak çökelip alttaki birimleri açllı uyumsuzlukla örtmüşlerdir. Dolmit-kireçtaşı yapılışlı Malm-Kretase yaşlı Cihandere neritik karbonatları, Çamiçi ve Dedebeleni formasyonlarını birlikte örter. Cihandere formasyonu, Maastrihtiyen yaşlı Hasancık formasyonunun killi-çörtlü pelajik karbonatlarıyla uyumludur. Bölgenin tüm yașlı birimleri bol fosilli neritik karbonatlardan yapılmıș Burdugaliyen'e ilişkin Mut formasyonuyla açılı uymsuz olarak örtülmüşlerdir.

Anahtar Kelimeler: Aladağ Birliği, Hadim napı, Devoniyen-Kretase istifleri.

\section{Abstract}

The allochthonous unit, known as Aladağ Unit or Hadim Nappe is around Aydınclk. In the area, the stratigraphic sequence starts by Asarlıkyaylası formation with Upper Devonian which made up of dolomit with macrofossil limestone, quartzite and shale. The Upper Devonian sequences are covered by Carboniferous aged Yarıcak formation, containing alternation of fossilliferous limestone and quartzite. With Girvenella, crinoid and fusulin limestones are the representativies of the Arpalık Formation. It underlies Yarıcak formation conformably, overlied by Late Permian Kuşakdağı formation disconformably. The Kusakdağı formation starts with shale-quartzite intercalation and continues with algae limestones. Early Triassic Gökçepinar formation is made up of oolitic-stratmatolithic limestone. At the top, the Gökçepınar formation shows transition to Early-Middle Triassic Göztaşl formation with shales, marls and with bivalve limestone. Lias-Dogger terrestrial Çamiçi formation is made of red conglomerate-sandstone-mudstone, which is covered by Dogger-Malm Dedebeleni formation including varius colors of mudstone, shale, limestone with semi-terrestrial character. Stratigraphic sequence continues with Malm-Cretaceous Cihandere formation, which is made up of dolomite and limestone. The Cihandere formation was covered by the Hasanclk formation as conformable, is represented by pelagics. In the Aydıncik area the whole sequences were covered by the Burdigalian Mut formation as 
DEU FMD 21(62), 633-647, 2019

unconformable, is represented by neritic carbonates.

Key words: Aladă̆ Unit, Hadim Nappe, from Devonian to Cretaceous sequences.

\section{Giriş}

Aydıncık çevresinin kaya birimleri (Şekil 1), Blumenthal [2] tarafindan "Hadim Paleozoyik Zonu veya Hadim Napına" atfedilmiştir. Özgül [14-16]), bölgedeki bu alloktonu "Aladağ Birliği" șeklinde ele almıștır. Turan [18, 20-21] söz konusu allokton dilimi, Gevne napı olarak tanıtır. Makaleye konu olan Hadim Napı, Aydıncık bölgesinde Üst Devoniyen-Üst Kretase kayalarını kapsar. Özgül [14-16] bu tektonik dilimi, Orta Toros'lar için Bolkardağı ile Bozkır birlikleri arasında bir ara tektonik dilim olarak kabul eder ve birçok yer bilimci de bu görüșe katılır. Ancak Aladağ Birliği veya Hadim Napı, Beyșehir-Hadim-Anamur-Silifke hattında hep en üst tektonik dilimidir [18-21]. Bölgede yapılmış bir çok çalışmaya rağmen, tektono-stratigrafik istiflenmeye ait düşünceler henüz netleşmemiştir. $\mathrm{Bu}$ makalede yöre stratigrafisinin son gözlem ve veriler ișığında tekrar açıklanması amaçlanmıştır.

\section{STRATİGRAFi}

İnceleme alanında Üst Devoniyen-Üst Kretase aralığını temsil eden Hadim Napı birimleri, Burdigaliyen resif karbonatları ile örtülmüş olup KB'dan GD'ya doğru genişleyen büyük bir senklinal içindedir (Şekil, 1). Çalışma alanı dișında kuzeyde Maastrihtiyen-Paleosen ofiyolit melanjına, güneyde ise Eosen flişoidlerine bindirir [20]. Hadim Napı birimleri; Bozkır - Hadim - Ermenek - Bozyazı hattında "Paleozoyik Hadim zonu" [2], "Toros fasiyesi" [1] "Orta Toros Birliği veya "Aladağ Birliği" [14-16], "Ermenek grubu" [3] ve "Bozyazı napı" [13] gibi adlarla incelenmiştir.

Aydıncık-Duruhan hattında Hadim Napında; Asarlıkyaylası (Üst Devoniyen), Yarıcak (Karbonifer), Arpalık (Alt Permiyen), Kuşakdağı (Üst Permiyen), Gökçepınar (Alt Triyas), Göztaşı
(Alt-Orta Triyas), Çamiçi (Liyas), Dedebeleni (Dogger-Malm), Cihandere (Malm-Kretase) ve Hasancık (Üst Kretase) formasyonları yer alır. $\mathrm{Bu}$ napın tüm formasyonlarını Mut formasyonu (Alt Miyosen) uymsuzluk örter (Şekil 2).

\subsection{Asarlıkyaylası formasyonu (Da)}

Aydıncık yöresinde Hadim Napının tabanındaki resifal karbonat mercekli, şeyl-kuvarsit ardışımı şeklindeki Üst Devon istifleri, Asarlıkyaylası formasyonunu olușturur. Birim adı Turan'dan [18] alınmıştır ve inceleme alanında Aydıncık sahil şeridinde dar bir alanda yüzeyler (Șekil 1). Asarlıkyaylası birimi çalışma alnında koyu grisiyah renkli, kalın tabakalı dolomit ve dolomitik kireçtaşı ile bașlar (Şekil 2, 3a). Üste doğru mavimsi gri, bol mercanll, brakiyopodlu, krinoidli kireçtaşı mercekli şeyl ve kuvarsitlere geçilir (Șekil 2, 3b). En üstte koyu gri-siyah renkli marn-şeyl-kireçtaşı-kumtaşı-silttaşı ardışımı izlenir. Mikroskopta kireçtaşı örnekleri; limonitle ornatılmış, iri kristalli, yoğun makro fosil kavkılı rekristalize bağlamtaşı-biyolitit şeklindedir (Şekil 3c). Kırıntılılar ise; kuvars kumlu silttaşı, ince taneli kuvars vake ve kuvars arenitlerdir. Asarlıkyaylası formasyonunun taban sinırı Aydıncık civarında görülmez. Bu sınır Bozyazı kuzeyinde Üst Paleosen-Orta Eosen flişoidleri ile tektoniktir [20]. Yarıcak formasyonuyla uyumlu olarak örtülen Asarlıkyaylası biriminin kalınlığl, inceleme alanında 200-300 m arasındadır. Disphyllum goldfussi Hexgonaria sp. gibi mercan tür ve cinsleriyle birlikte briyozoer, spiriferit tipi brakiyopod, krinoid formları içeren birim, Geç Devoniyen yaşlıdır. Asarlıkyaylası biriminin orta-üst düzeylerinde yoğunlașmıș kuvarsitik kumtașı egemen kırıntılılar, gel-git akıntıları etkinliğinde ve tektonik açıdan duraylı bir çökel alanını gösterir. 
DEU FMD 21(62), 633-647, 2019

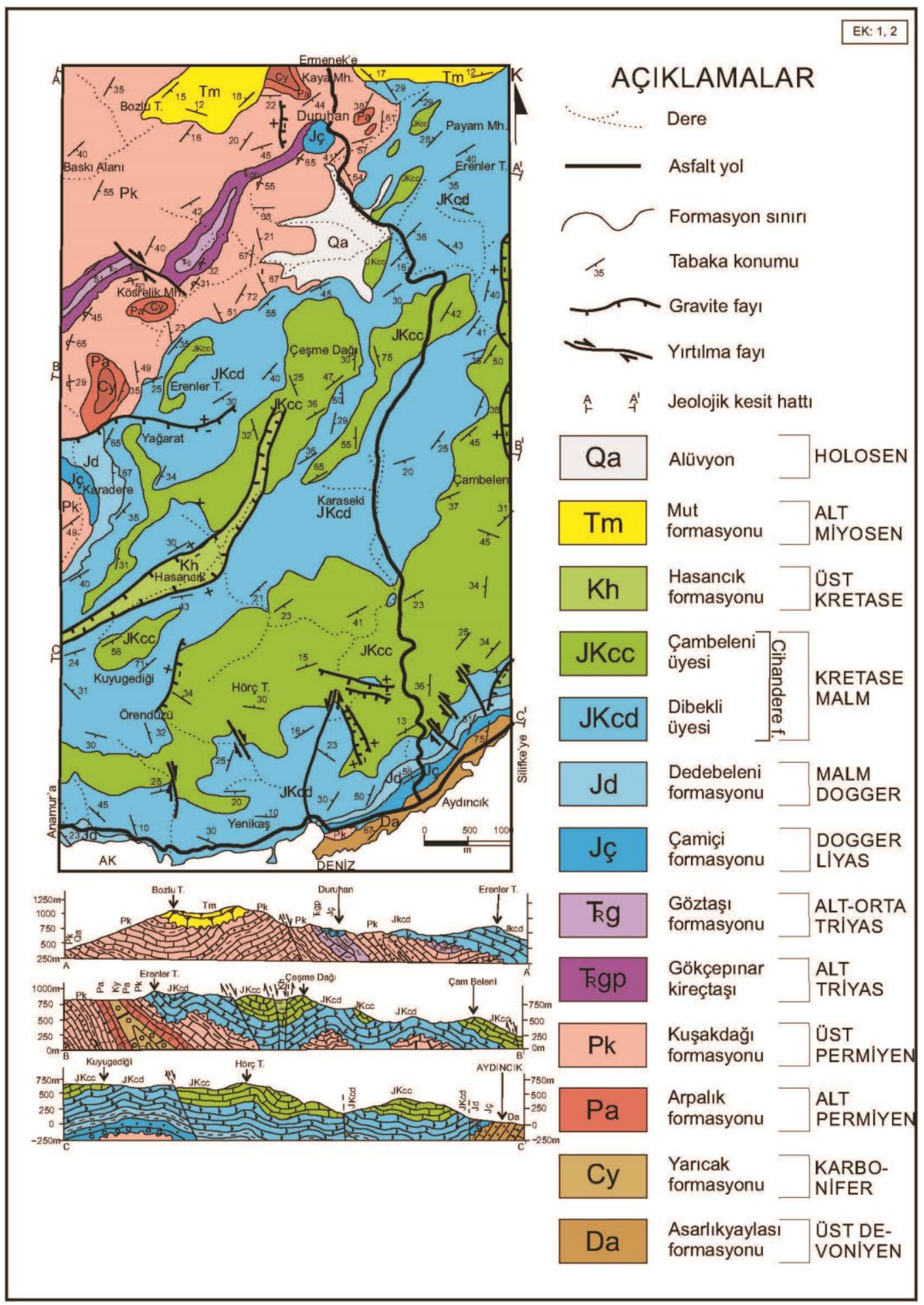

Şekil 1. İnceleme alanının jeoloji haritası ve jeolojik kesitleri. 
DEU FMD 21(62), 633-647, 2019

\begin{tabular}{|c|c|c|c|c|c|}
\hline 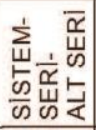 & $\sum_{\substack{\infty \\
0}}^{\infty}$ & 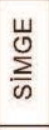 & $\frac{\stackrel{y}{\vec{z}}}{\underline{\underline{z}}}$ & LITOLOJI & AÇIKLAMALAR \\
\hline $\begin{array}{l}\text { KUVA- } \\
\text { TERNER }\end{array}$ & $\begin{array}{l}\text { ALOV- } \\
\text { YON }\end{array}$ & $\stackrel{\pi}{0}$ & हี & & $\begin{array}{l}\text { Çakıl-kum- silt ve kilden yapilı gevşek kırıntılılar. } \\
\text { AÇILI UYUMSUZLUK }\end{array}$ \\
\hline 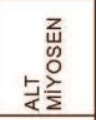 & $\frac{5}{\Sigma}$ & $E$ & 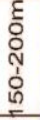 & & $\begin{array}{l}\text { Gri bej renkli, orta-kalın tabakalı,bol makro fosilli } \\
\text { kireçtaşı, killi kireçtaşı }\end{array}$ \\
\hline 离离崖 & 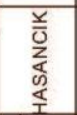 & ร & हัे & & $\begin{array}{l}\text { Sarımsı gri, koyu sarı, bordo renklerde ince-orta tabakalı, } \\
\text { sıkışık kıvrimlı, bol pelajik fosilli, çörtlu kireçtaşı, killi kireçta- } \\
\text { şı, mam, şeyller }\end{array}$ \\
\hline 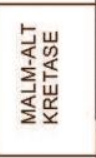 & 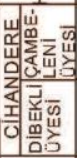 & 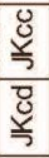 & 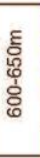 & & $\begin{array}{l}\text { Açık gri renkli, bol eklemli, orta-kalın tabakall, alg ve } \\
\text { foraminifer içerikli sığ şelf karbonatları } \\
\text { Gri- kül renkli, orta-kalın katmanlı ve şekersi dokuda } \\
\text { dolomit- dolomitti kireçtaşı }\end{array}$ \\
\hline 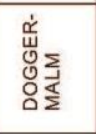 & 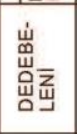 & 꾸 & छั & 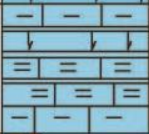 & $\begin{array}{l}\text { Alacalı renkli, ince- orta katmanlı killi kireçtaşı,mam,şeyl, } \\
\text { çamurtaşı, dolomitti kireçtaşı }\end{array}$ \\
\hline 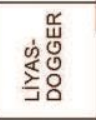 & 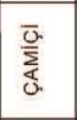 & 所 & $\frac{\mathrm{c}}{\mathrm{c}}$ & 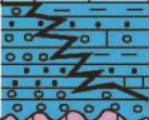 & $\begin{array}{l}\text { KımızıII- kahve renkli, kalın ve çapraz tabakalı çakiltaşı } \\
\text { egemen kumtaşları ve çamurtaşları } \\
\text { ACILI UYUMSUZLUK }\end{array}$ \\
\hline 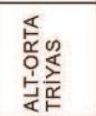 & 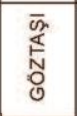 & ס & 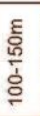 & 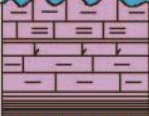 & $\begin{array}{l}\text { Alacalı renklerde şeyl, bol bivalvil killi kireçtaşı, marn, } \\
\text { çamurtaşı }\end{array}$ \\
\hline 点交 & 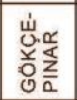 & 응 & 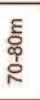 & $\frac{1}{\frac{1}{1}}$ & Gri- açık renkli, orta katmanlı, stramatolitli ve oolitil kireçtaşı \\
\hline 它咅z & 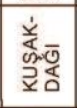 & $\frac{y}{0}$ & छे & & $\begin{array}{l}\text { Seyrek olarak kuvarsit- şeyl ara katkıları içeren koyu-gri } \\
\text { siyah renkli, bol algli(en çok Mizzzal'ar görülur), orta } \\
\text { tabakalı ve bol eklemli kireçtaşları } \\
\text { ACIILI UYUMSUZLUK }\end{array}$ \\
\hline 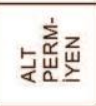 & 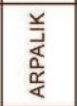 & ¿ & స్ స్ & & $\begin{array}{l}\text { Yeşilimsi-koyu sarı-kahvemsi ve kırmızımsı renklerde, } \\
\text { orta-kalın katmanlı, bol fuzulinli ve krinoidli onkoidal } \\
\text { kireçtaşłarı }\end{array}$ \\
\hline 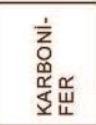 & $\frac{\frac{x}{0}}{\frac{d}{\alpha}}$ & త & E్ & & $\begin{array}{l}\text { Gri,boz ve sarimsı renklerde, orta-kalin katmanli, bol } \\
\text { fuzulin, krinoid ve brakiyopodlu kireçtaşı ile kuvarsit } \\
\text { ardalanması }\end{array}$ \\
\hline 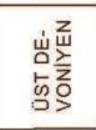 & 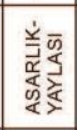 & வ & 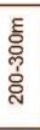 & 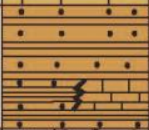 & $\begin{array}{l}\text { Bol mercan, krinoid ve brakiyopod içerikli resifal kireçtaşı } \\
\text { mercekleri de kapsayan gri-boz renkli kuvarsit, şeyl ve } \\
\text { dolomitler }\end{array}$ \\
\hline & & & & 10 & Paleojen flişoidleri veya Senoniyen melanjı \\
\hline
\end{tabular}

Şekil 2. İnceleme alanının stratigrafik dikme kesiti 
Söz konusu kırıntılılara eșlik eden kokina yığını halindeki karbonat mercekleri, resifli denizel ortam koşullarını yansıtır. Üst seviyelerdeki organik materyal içeriği yüksek koyu gri-siyah șeyller ise, su altı redüktör bir ortama işarettir. Asarlıkyaylası birimi Hadim-Anamur-Silifke yörelerindeki Anamur fasiyesinin Üst Devon istifi [1], Gölboğazı [13, 16], Mulumu [3], Göksu [11] ve Akdere [3, 7] formasyonlariyla korelatiftir.

\subsection{Yaricak formasyonu (Cy)}

Çalışma sahasının kuzeyinde gözlenen fosilli kireçtaşı-kuvarsit nöbetleşmesi şeklindeki Karbonifer istifi, Yarıcak formasyonunu olușturur (Șekil 1-2). Birim adı Turan [18]'dan alınmıştır. Yarıcak birimi, YağaratDuruhan çizgisinin kuzeyindek dereleri takip eden antiklinaller boyunca yüzeyler (Șekil 1).

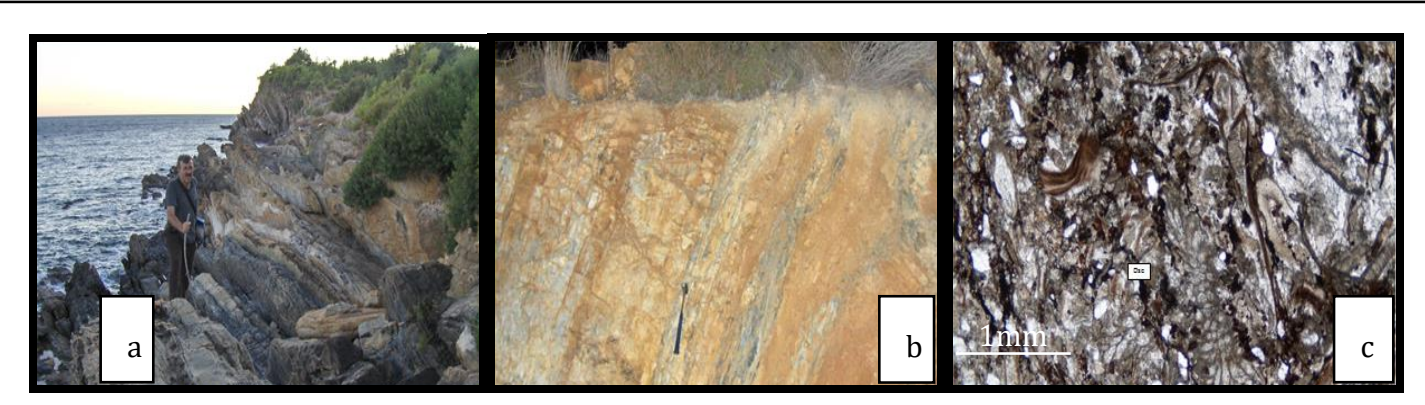

Şekil 3. Aydıncık sahilinde Asarlıkyaylası birimine ait fosilli kireçtașı-șeyl-kuvarsit ardıșımlarının görünüşü (a ve b) ve fosilli kireçtaşlarını oluşturan yoğun brakiyopodlu kumlu biyosparitler (c).

Yarıcak formasyonu laminalı, koyu gri, ortakalın katmanlı, kumlu kireçtaşları ile başlar ve düşey yönde kahvemsi boz renkli yumrulu kireçtaşlarına geçer (Şekil 2, 4a). Daha üstlerde bordo kuvarsitler ile pembe renkli, laminalı, bol mercanl,, brakiyopodlu, krinoidli ve kuvars kumlu kireçtaşları görülür. Kumtaşları kuvars veya limonit çimentolu, yarı yuvarlak-toparlakça, olgun kuvars içerikli kuvars arenitlerdir. Formasyonun karbonatları biyosparit, kumlu oosparit, fosilli oosparit ve biyointrasparitlerdir (Şekil 4b, c). Alt Permiyen'e ait Arpalık formasyonuyla uyumlu olan Yarıcak formasyonunun kalınlı̆̆ı, yöredeki referans kesitlerinden 100 m'dir. Yarıcak formasyonunda; Pseudoendothyra sp Neoarchaediscus sp.,Ozowainella sp., Globivalvulina sp., Diplosphaerina sp., Millerella sp., Archaediscus sp., Earlandia sp., Schubertella sp., Tubertina $s p$. ile Moellerites sp., Fusulinella sp, (Şekil $4 b$, c) gibi mikro faunalar ile Fenestella $s p$., Linoproductus sp., Productus sp. ve Zaphrentis $s p$. gibi makro cinslere, ekinid diken ve levhalarına (Șekil 3c) rastlanmış olup, formasyona Karbonifer yaşı ön görülmüştür. Yarıcak biriminin lito ve biyofasiyes özellikleri (Şekil 2, 4), çökelimin sığ-sıcak- yüksek enerjili Y zonunda [9] gerçekleștiğini gösterir. Karbonatlarla ardalanan ve demiroksitlerce zengin ve az yuvarlak kuvars kumtaşları, kıyıya yakın bir oksidasyon kaynağını gösterir. Dolayısıyla Yarıcak formasyonunun ortamsal gelișimi, resif ardiresif düzlüğü fasiyeslerini[23] yansitmaktadır. Mulumu [3] ve Göksu [11] formasyonları, Aladağ Birliğinin tabanını oluştura Geç Devon yaşlı Asarlıkyaylası [18] ve Yarıcak birimlerinin her ikisini birden karşılarken; Belpınartepe formasyonunun [4] alt bölümü ve Değirmendere formasyonu [19] Yarıcak formasyonuna karşılık gelmektedir.

\subsection{Arpalık formasyonu (Pa)}

Yarıcak formasyonunu uyumlu örten ve bol fosilli kireçtaşından yapılı (Şekil 4) Alt Permiyen istifi, Arpalık formasyonunu teşkil eder. Birim adı Turan [18]'dan alınmıștır. Bu birim inceleme alanının kuzeyindeki dereler boyunca açılan antiklinallerde yüzlek verir (Şekil 1). Arpalık formasyonun en altta yeşilimsi sarı, orta-kalın tabakalı kireçtaşlarında, Girvenella tüpsel alglerinin oluşturduğu 0,5-1 cm çaplı onkolitler, 
oldukça yaygındır. Onkolitlerin çekirdeğinde ekseri schwagerinid tipi bir fuzulin, bazen bir brakiyopod kavkı parçası bulunur. Çekirdek etrafında dıșa doğru genișleyen alg tüpleriyle sarılmış bu düzeyler, Girvenella'lı kireçtaşı seviyeleridir. Bunların üstünde sarımsı- boz renkli, 5-6 mm irilikte bol fuzulinli bir düzey yer alır. Daha üstte koyu gri-gri renkli, bol krinoidli, yer yer briyozoa-mercanbrakiyopod içerikli kireçtaşlarına geçilir. Formasyonun karbonatlarl; biyosparrudit, biyointrasparit ve biyolitit şeklindedir. Arpalık formasyonu, Kuşakdağı formasyonu ile uyumsuzdur. Alt Permiyen ve Üst Permiyen birimleri arasinda belirgin bir açısallık görülmezken, aşınım sonucu, Karbonifer üzerine doğrudan Üst Permiyen gelebilmektedir. Hatta çalıșma alanı dıșında Bozyazı'nın Kök Mahallesi'nde Üst Devoniyen üzerinde direkt Üst Permiyen'in gelmesi [20], Geç Permiyen öncesi bir karalașmayı gösterir. Arpalık formasyonunun kalınlığı, en çok $120 \mathrm{~m}$ kadardır. $\mathrm{Bu}$ birimin numunelerinde; Robustschwagerina tumide, Eoturbertina reitlinger, Globivalvulina parva, Kwantoella fujimatoi, Nodisinella sp., Bradyna sp., Pseudoschwagerina sp., Paleotextularia sp., Tubiphides sp., Cacivertella sp., Girvenella sp., Tetrataxis sp., Tiriticites sp. gibi cins ve türlere rastlanmış ve birime Erken Permiyen yașı verilmiștir. $\mathrm{Bu}$ birimin litofasiyes ve biyota özellikleri, Erken Permiyen'deki çökelmenin, resifli bir gel-git altı deniz ortamı olduğunu desteklemektedir.

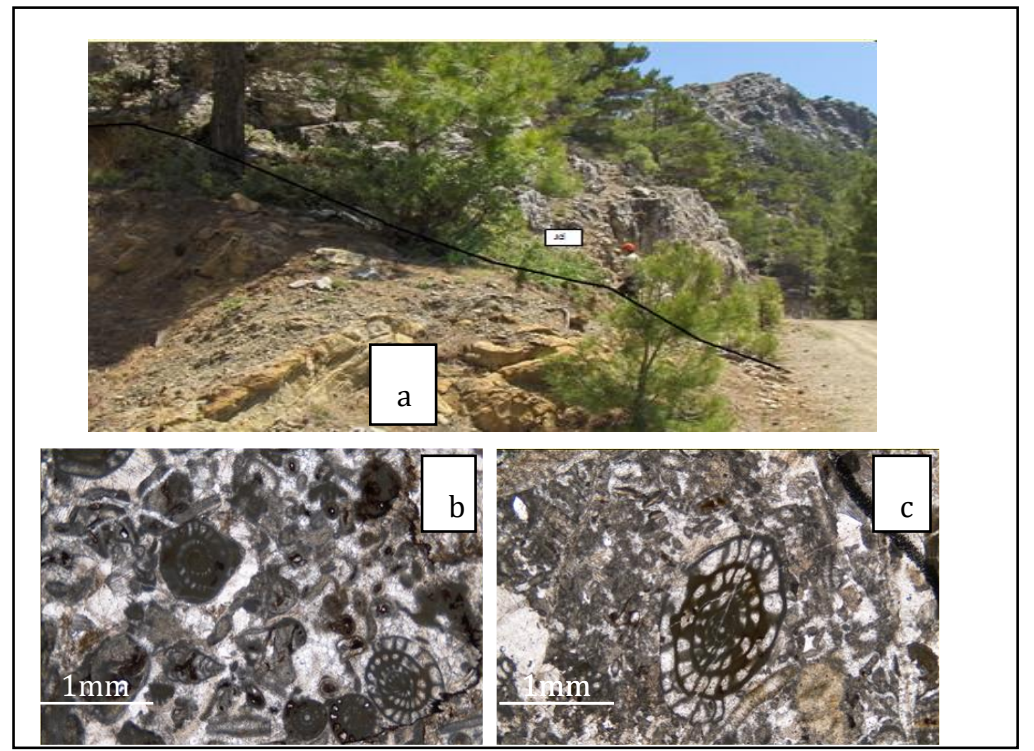

Şekil 4: Yağarat kuzeyinde Yarıcak formasyonunun karbonat ve kırıntılıları üzerine açılı uyumsuzlukla Dibekli dolomitinin gelişi (a).Yarıcak formasyonunun kuvars kumlu biyosparitleri içinde yarım (b) ve tam formlar halinde Fusulinella sp. ile krinod disklerinin (c) mikrofotografları.

\subsection{Kuşakdağı formasyonu (Pk)}

Kuşakdağı formasyonu kuvarsit, şeyl ve algli kireçtașı içerikli Üst Permiyen istiflerinden oluşur (Şekil 2, 5). Birim adı Turan [18]'dan alınmıștır. İnceleme sahasının en kalın ve geniş yayılımlı birimi olan Kuşakdağı formasyonu, Baskı Alanı-Kösrelik MahallesiDuruhan Köyü civarları ve Kara Dere dolaylarında yüzeylemektedir (Şekil, 1). 

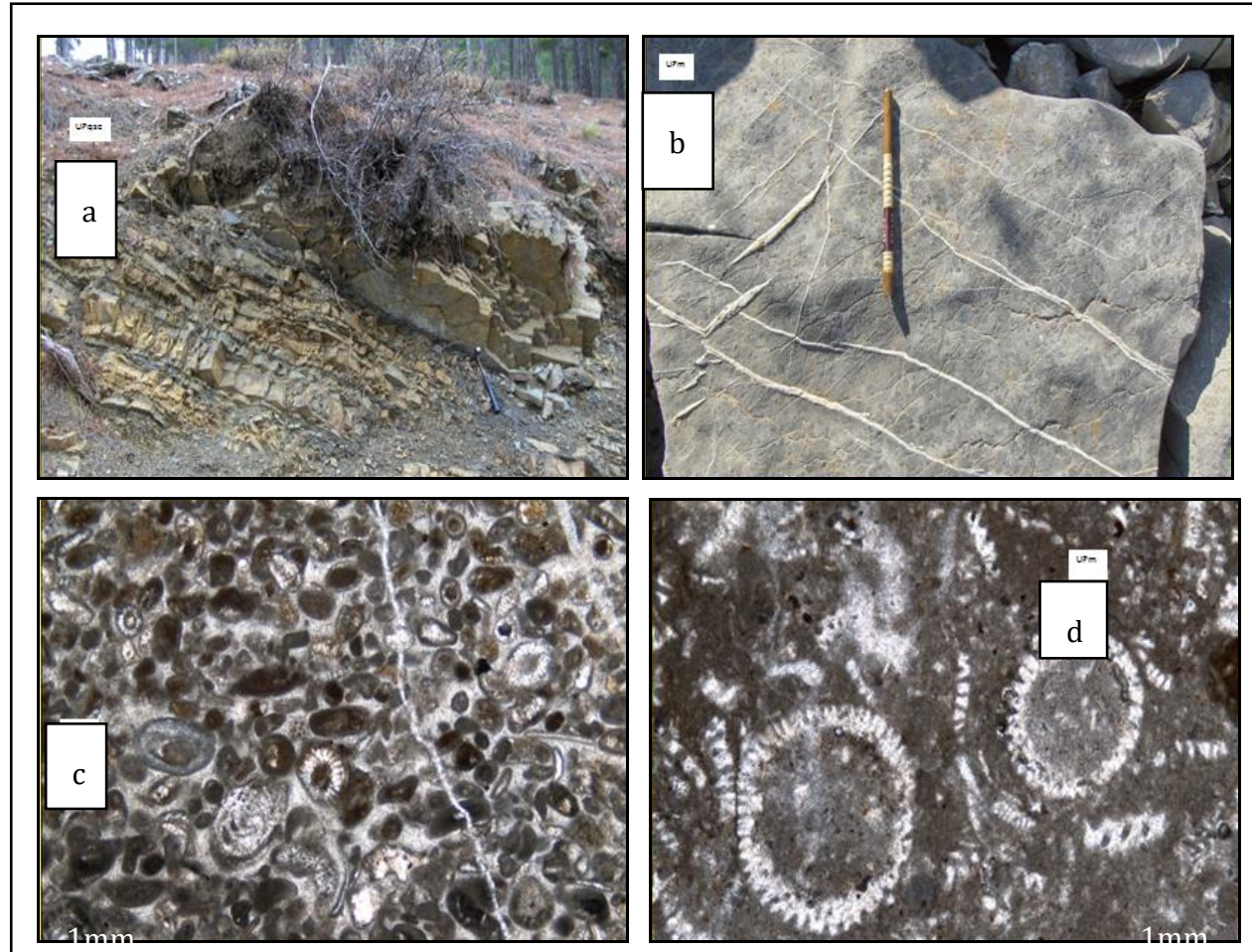

Şekil 5. Duruhan kuzeyinde Kușakdağı formasyonuna ait arazi görüntüleri (a ve b) ile bol Gymnocodium'lu biyosparit (c) ve biyomikritlerin (d) mikro fotografları.

Kuşakdağı biriminin egemen litolojisi, koyu gri-siyah renkli, çok yoğun algli (Mizzia sp. egemen ) ve bitümlü kireçtaşlarıdır (Şekil 2, 5). Yer yer dolomitize tabakalar içeren Kuşakdağı formasyonunun karbonantları; çoğunlukla biyomikritlerdir ve biyomikrudit, biyosparit, biyointrasparit mikrofasiyesleri de olağandır (Şekil 5c, d). Formasyonun kumtaşları yuvarlak, iyi boylanmış, olgun kuvarslardan yapılmış kuvars arenitlerdir. Alt Triyas'a ait Gökçe-pınar birimi ile uyumlu örtülen Kuşakdağı biriminin kalınlığı, 800 m'dir. Hemigordius sp., Paraglobivalvulina sp., Globivalvulina sp., Gymnocodium sp., Pseudovermiporella sp. Permocalculus sp., Pachipholia sp., Dagmarita sp., Geinitzina sp., Kamurana sp., Mizzia sp., ile. gibi mikrofaunalar ve Hexagonaria sp., Syringopora sp., Belemnites sp. gibi makro fosiller içeren Kuşakdağı formasyonuna Geç Permiyen yaşı verilmiştir. Formasyonun litolojik gelişimi, Mizzia ile Hemigordius'ların bolluğu ve diğer biyotalar, çökel alanının resif ardı-lagün bölgelerini de içeren gel-git altı deniz olduğunu gösterir. Karbonatları kesintiye uğratan temiz kuvars kumtaşı ve organik materyal içerikli koyu gri şeyller, genelde Irwin [9]'in Z-kuşağında gerçekleșen sedimantasyonun, zaman zaman Y-kuşağına kaydığına ve çökelimin ayrıca sınırlı platformda [22] gerçekleştiğine delildir. Arpalık ve Kuşakdağı birimleri beraberce Bozkır-Hadim-Taşkent'te Çekiçdağı [16], Sarıveliler'de Gavuralanı ve Dikmentepe [12], Ermenek'te Dumlugöze [3] ve Belpınartepe [4] Silifke'de Ağıldere [5], Yarıktaş ve Akkorum [19], Bozyazı-Aydıncık çevresinde yine Çekiçdağı [7] formasyonları ile deneştirilebilir.

\subsection{Gökçepınar kireçtaşı ( $\mathrm{T}$ gp)}

Gökçepınar formasyonu, stromatolitik-oolitik Alt Triyas karbonatlarından oluşmaktadır ve formasyon adı Turan [18]'dan alınmıștır. Bu birim Duruhan Köyü'nün batısında KD-GB gidişli devrik bir senklinal ekseni boyunca 
yüzeyler (Sekil 1). Gökçepınar kireçtașı tabanda $20 \mathrm{~m}$ kalınlıklı pembemsi krem renkli, ince-orta katmanl,, stromatolitik alg laminaları içeren, kireçtaşı ile başlar (Şekil 6a). Daha sona benzer renk ve görünümdeki oolitik kireçtaşlarına geçilir. Daha üstte glokoni içeren hafif rekristalize seviyelerden sonra, demirli çözeltilerle ornatılmış küçük gastrapodlu düzeyler görülür. En üstte de ince bir parçalı kireçtaşı seviyesi izlenir. Gökçepınar istifinin alt seviye örnekleri; algal laminalı, stilolitli, iri kalsit damarlı ve mikritik kökenli kristalize kireçtaşlarıdır (Şekil 6b). Oolitik düzeyler ise; mikritik parçalar etrafında konsantrik büyüyen 0.2 $0.4 \mathrm{~mm}$ 'lik oolitler ile $2-3 \mathrm{~mm}$ 'lik pizolitleri kapsayan oosparitlerdir.

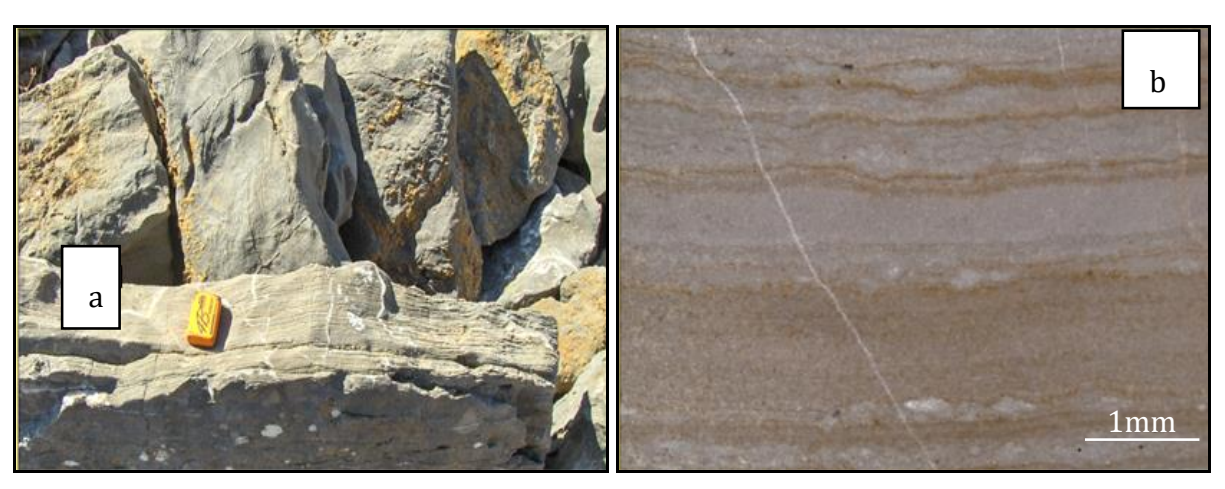

Şekil 6. Duruhan batısında Gökçepınar kireçtaşının makro (a) ve mikro (b) görüntüleri.

Altta Kușakdağı, üstte Göztașı formasyonu ile uyumlu olan Gökçepınar kireçtaşının kalınlığı, 60-70m kadardır. Bu formasyonun stratigrafik yeri ve önceki araștırıcıların paleontolojik bulguları $[11,14,16]$ dikkate alındığında, birimin yașı Erken Triyas'tır. Gökçepınar kireçtaşını oluşturan algal mikritik fasiyesler, başlangıçta birimin dalga tabanı altında düşük enerji zonunda çökeldiğini gösterir. Su enerjisi yükselimiyle karbonat çamuru ortamdan uzaklaștırılmıs ve çalkantılı koşullarda oolitik-pizolitik fasiyesler şekillenmiștir.

\subsection{Göztaşı formasyonu ( $\mathrm{T} \mathrm{g}$ )}

Gökçepınar kireçtaşı üzerine uyumlu olarak gelen, Alt-Orta Triyas'a ilişkin şeyl-marn-killi kireçtaşı nöbetleşmesi, Göztaşı formasyonu oluşturur. Formasyon adı Turan'dan [18] alınmıstır. Birim Duruhan'ın batısında KDGB uzanımlı devrik bir senklinalin çekirdeğinde yüzeyler (Şekil 1). Bu birim altta alacalı renkli şeyler ve bunlara refakat eden 2-3 m kalınlıklı koyu sarı killi karbonat ara seviyeleriyle bașlar. Üste doğru sıkıșık kıvrımlı șeyllere, boz renkli, 6-7 cm kalınlıklı kireçtaşı-marn ara tabakaları da katılır (Şekil 7a). Göztaşı formasyonunun orta-üst kesimlerinde, şeyl ara tabakalı sarı boz renkli, ince-orta tabakal,, bol bivalvligastrapodlu-vermesli-ammonidli, yumrulu killi kireçtaşlarına (Şekil 7b) rastlanır. En üstte ince-orta tabakalı, sarımsı renkli dolomitik kireçtaşları görülür. Göztașı biriminin marnları yoğun olark killi mikrit, kireçtaşları ise biyomiksparit, fosilli killi mikrit, intramiksparit ve hafif kristalize kireçtaşı mikrofasiyeslerini sunmaktadır. Gökçepınar kireçtaşını uyumlulukla örten Göztaşı formasyonunun üst sınırı, harita alanında atmosfere açıktır. Gömülü olduğu alanlarda açısal uyumsuzlukla Çamiçi formasyonuyla örtülmüş olmalıdır (Șekil 1, 2). Birimin referans kesitlerinden ölçülen stratigrafik kalınlığı 100-150 m kadardır. Göztaşı formasyonunun alt kesimlerindeki alacalı şeyllerde Tirolites $s p$. ve Naticella sp. gibi ammonit ve gastrapodlara rastlanmıșken, orta-üst seviyelerdeki karbonatlarda; Meandrospira pusilla, Cyclogyra mahajeri, Glamospirella sp, Calcitornella sp., Glamospira sp, cins ve türleri görülmüș olup bu birimine Erken-Orta Tiyas yaş konağı ön görülmüştür. 


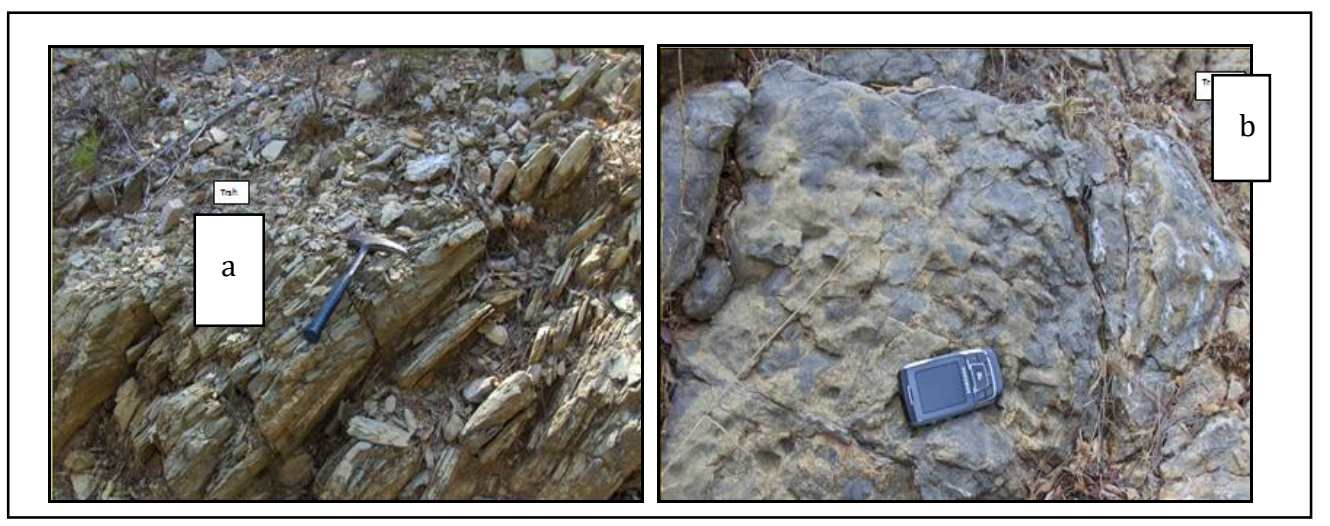

Şekil 7. Duruhan batısında Göztaşı biriminin alacalı şeylleri (a) ve killi-yumrulu karbonatarı (b).

Göztașı formasyonuna ait șeyller, yağıșlı bir klimada çökelme havzasına ulaşan terrijen malzeme bolluğunu gösterirken, kireçtaşı ara tabakaları terrijen gelimin duraksadığ dönemleri simgeler. Üste doğru izlenen bol bivalv, gastrapod, ammonit ile foraminifera içerikli killi karbonatlar, dinginleșen derince bir denizde, karbonat çökeliminin egemenliğini gösterir. Birimin en üst kesimlerindeki, şeylmarn ara katkıl dolomitik karbonatların lito ve biyo fasiyes özellikleri, benzer çökelme şartlarının devamlılı̆̆ına delildir. Gökçepınar ve Göztaşı formasyonları birlikte, Orta Toroslar'daki Göktepe [3], Kizılkuzlukdere [4], Isbatlı [8], Haydar [11], formasyonlarının altorta kesimlerine ve Gevne [14] formasyonun ise alt bölümüne karşllı gelmektedir.

\section{7. Çamiçi formasyonu (Jç)}

Alttaki birimleri açılı uyumsuzlukla örten kızıl renkli karasal Liyas-Dogger istifi, Çamiçi formasyonu oluşturur. Formasyon adı, bu istiflerin en iyi görüldüğü Çamiçi Mahallesine (Beyreli-Hadim) atfen kullanılmıștır [18]. Bu birimin yüzlekleri, Aydıncık Merkez'inde KDGB uzantısında Soğuksu Mahallesi'ne kadarki kesimlerde, Karadere ve Duruhan civarlarında bulunmaktadır (Şekil 1). Çamiçi formasyonu baskın olarak kızıl, koyu sarıkahverenkli, orta-kalın ve çapraz katmanlı, orta-iyi derecede yuvarlaklaşmış ve boylanmıș, yuvarlak-yassı çakılllı, homojenpolijenik konglomeralarından oluşur. Yanal ve düșey yönde kızll renkli kumtaşı ve çamurtaşlarına geçebilen birimin çamurlu düzeyleri arasında, bol gastrapodlu ve killi kireçtaşı kamaları izlenebir. Az yuvarlakköşeli, kötü boylanmış, toparlakça kuvars- karbonat ve metamorfik parçalar içeren kumtaşları, karbonat çimentolu yarı litik arenitlerdir. Karbonat mercekleri ise algal tane, ostrakod-gastrapod ve kil topaciklı dismikritlerdir. Karbonatların alt ve üstündeki alacalı çamurtaşları ise, köşeli kuvarslı, karbonatlı ve demiroksitli taneler ile kil nodülünden oluşur. Alttaki kayaları açısal uyumsuzlukla örten karasal Çamiçi formasyonu, üstte yarı karasal nitelikli Dedebeleni birimiyle uyumlu ve yanal-düşey geçişlidir. Yapılan kesit ölçümünde Çamiçi biriminin kalınlığı, 100-150 m kadardır. Bu formasyonun çakıllarında Karbonifer, Permiyen ve Orta Triyas'a ait fosillere erişilmiştir. Çamurlu seviyeler ise, tanıtman olmayan gastropod-ostrakod-spor ve polenleri içermektedir. Çamiçi formasyonu, üzerindeki Dedebeleni formasyonuyla birlikte bir çok yayında, Geç Triyas olarak yaşlandırılmıştır $[4,7,13,16)$. Ancak Toroslar'da, Orta-Geç Triyas geçişinde etkin bir orojenik evre bilinmediğinden, birimin tabanındaki açlı uyumsuzluk, Erken Kimmeriyen orojenik fazıyla ilişkili olmalıdır. Toroslar'da Jura transgresyonunun yayginlığı ve üst formasyonun Dogger-Malm yaşlı oluşu, Çamiçi formasyonunun olasıllkla Erken-Orta Jura'da çökeldiğini gösterir. Sarıveliler dolaylarında çalışan Göktepe ve Güvenç'de [6] bu birime karşıllk gelen stratigrafik seviyelerin, Liyas olduklarını söylemişlerdir. Çamiçi ünitesinin litoloji özellikleri ve fasiyes geometrileri, birimin bir aşınım dönemi ardından oluşan alüvyal yelpaze dizileri olduklarını anımsatır. Buda bize Çamiçi formasyonunun çökeldiği yerin, örgülü-geçici akarsu etkinliğinde bir paleocoğrafya 
olduğunu hatırlatır. Yaygın kırmızı renk, çapraz tabakalanma, sıcak karasal koșulları yansitırken; mercek ve kamalar halindeki dismikritler ise, bu süreçte bölgede oluşan sınırlı göl alanlarını destekler.

\subsection{Dedebeleni formasyonu (Jd)}

Çamiçi formasyonuyla uyumlu, bazende onunla yanal-düșey geçişli olan ve dolomit ara seviyeli çamurtaşı-kiltaşı içerikli Dogger-Malm istifleri, Dedebeleni formasyonunu oluşturur. Birim adını Turan [18] vermiștir ve çalıșma sahasında Aydıncık kent merkezi, Soğuksu, Aydıncık-Bozyazı yolunun sahil tarafi ve Karadere kuzeyi, birimin ince şeritler halinde mostra verdiği yerlerdir (Şekil 1). Tabanda kırmızımsı-yeșilimsi gri çamurtaşlarıyla başlayan birim, üste doğru kumtaşı ve çok ince taneli çakıltaşı ara katkılı, sarı boz renkli killi kireçtaşı-marn-çamurtaşı ardışımına geçer. Açlk kahverenkli sarımsı çamurlu seviyeler, birkaç kez tekrarlandıktan sonra, en üstte kül renkli killi kirçtaşı-şeyl-marnlarla ardışık dolomitli tabakalar yer alır. Dolomit kristalli killi karbonatlarda, kilin aşınımıyla oluşmuş kovuklu yapilar mevcuttur. Formasyonun karbonatları killi dismikrit, pelloidal killi mikrit, dolosparit, ilksel çatısı bozulmuş intrabiyosparit iken, çamurtaşı ardalı greler litik vakedir. Cihandere formasyonuyla uyumlu örtülen Dedebeleni formasyonunun kalınlığı, Aydıncık çevresinde 100-150 m kadardır. Salpingoporella annulata,
Salpingoporella sp., Actinoporella $s p$., Glomospira sp. ve Glomospirella sp. gibi fosiller içeren bu birime Orta-Geç Jura yaş konağ önerilmiștir. Dedebeleni biriminin kapsadığ sinırlı bentik foraminiferli ve algli-dismikritlidolomitli mikrofasiyesler ve bunlarla ardalanma gösteren çamurlu seviyeler, gel-git düzlügüu-lagün geçişlerinde, yarı karasal-çok sığ bir deniz ortamına işarettir. Selley [17]'e göre karışık kıyı olan bu çökel ortamı, aynı zamanda Z-kuşağının gerisindeki platform evaporitleri (22) kuşağıdır. Orta Toroslar'daki Gevne konglomerası [8], Göktepe formasyonunun [3] üst bölümü ile Balcllar [11] ve Boztepe $[4,19]$ formasyonları, Çamiçi ve Dedebeleni formasyonlarına karşılık gelmektedir.

\subsection{Cihandere formasyonu $(\mathrm{JKc})$}

Dolomitlerle başlayıp orta-üst kesimlerde kireçtaşlarıyla devam eden Jura-Kretase karbonatları Cihandere formasyonunu oluşturur. Birim adı Kuşçu [11]'dan alınmıştır. Formasyon Aydıncık-Yenikaş, Yağarat, Karaseki, Örendüzü ile Erenler Tepe, Hörç Tepe, Çeşme Dağı ve Çambeleni hattında geniș ve kalın yüzlekler sunar (Şekil 1, 2, 8). Altta bulunan dolomitik karbonatlar, Koç vd., [10] tarafindan "Dibekli dolomit üyesi (JKcd)", kireçtaşı tabakalardan yapılı üst bölüm ise "Çambeleni kireçtaşı üyesi (JKcç)" şeklinde tanıtıldığından, üye adları bu çalışmada da kullanılmıştır.

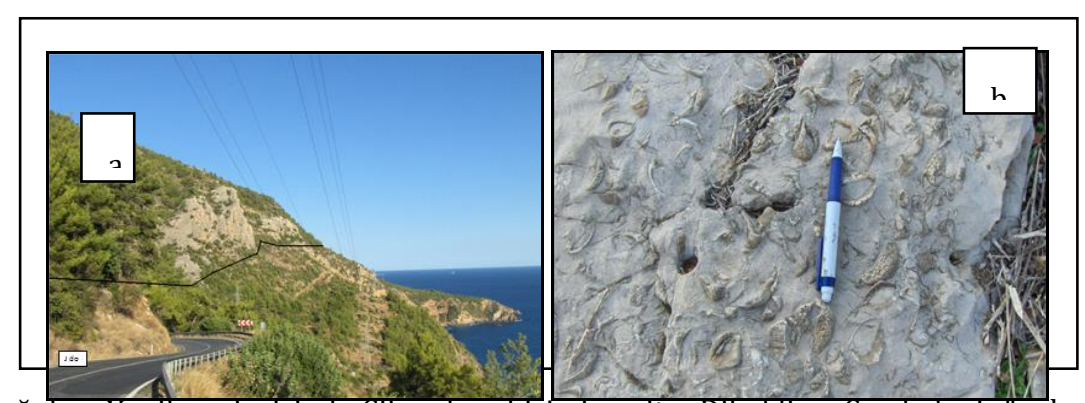

Şekil 8. Soğuksu-Yenikaş çizgisinde Cihandere birimine ait Dibekli ve Çambeleni üyelerinin sınır ilişkisi (a) ve Çambeleni kireçtaşının alt-orta kesimlerini oluşturan Litotis'li seviyeler (b).

\section{Dibekli dolomit üyesi (JKcd):}

Gri-koyu gri renkli, orta-kalın katmanlı, bol eklemli, rekristalize ve şekersi dokulu dolotașları, Dibekli üyesini oluşturur. Soğuksu-Yenikaş ve Ak Deniz sahil şeridi ile Hasancık-Yağarat hattının doğusu, Karaseki, Erenler T. çevresi Dibekli üyesinin yüzlek alanlardır (Şekil 1). Bu üyeye ilişkin ince kesitlerede; 0.2-0.3 mm irilikte ve öz-yarı öz şekilli dolomit romboederleri gözlenir. Dolomitlere yer yer kalsitler eşlik edebilir. Bu örnekler dolosparit mikrofasiyeslidirler. Altta Çamiçi ve Dedebeleni formasyonlarıyla yanal-düşey geçişli olan dolomit üyesinin kalınlığı, 250 m ölçülmüştür. 


\section{Çambeleni kireçtaşı üyesi (JKcç)}

Aydıncık yöresindeki gri renkli, orta-kalın katmanlı Malm-Kretase neritik kireçtaşları, Çambeleni üyesini oluşturur. Bu üye Örendüzü doğusu, Hörç Tepe, Çeşme Dağı ve Çambeleni dolayında yüzeyler. Örendüzü'nün KD'sunda Çambeleni üyesinin alt kesiminde, yer yer Litotis cinsi bivalvlerin görüldügü klavuz bir seviye vardır (Şekil, 8b). Litotis'li seviyelerden sonra boz renkli, yer yer rekristalize olmuş, kahvemsi ve açık gri yumrular içeren kireçtaşına geçilir. Mikroskop çalışmalarında bu yumruların, bivalv kavkısı etrafında sarılmış onkoidler olduğu görülür. Çambeleni kireçtaşı üyesinin en üstünde rudistli seviyeler de mevcuttur. İnce kesit çalışmalarında bu kireçtaşlarının; dismikrit, biyopelintrasparit, istiflenmiş biyomikrit, biyointramikrit, intramikrit, seyrek biyomikrit mikrofasiyesli olduğu gözlenmiştir (Şekil, 9). Dibekli dolomiti üzerinde uyumlu olarak gelen Çambeleni üyesinin kalınlığı $200-400 \mathrm{~m}$ arasında değișmektedir.

İnceleme alanında kalınlığı 600 m'yi bulan Cihandere formasyonu, Aydıncık yöresinde zirveleri oluşturur (Şekil 1) ve Duruhan kuzeyinde izlendiği gibi Burdigaliyen yaştaki Mut formasyonu ile açılı uyumsuz olarak örtülür $[4,11,23]$.
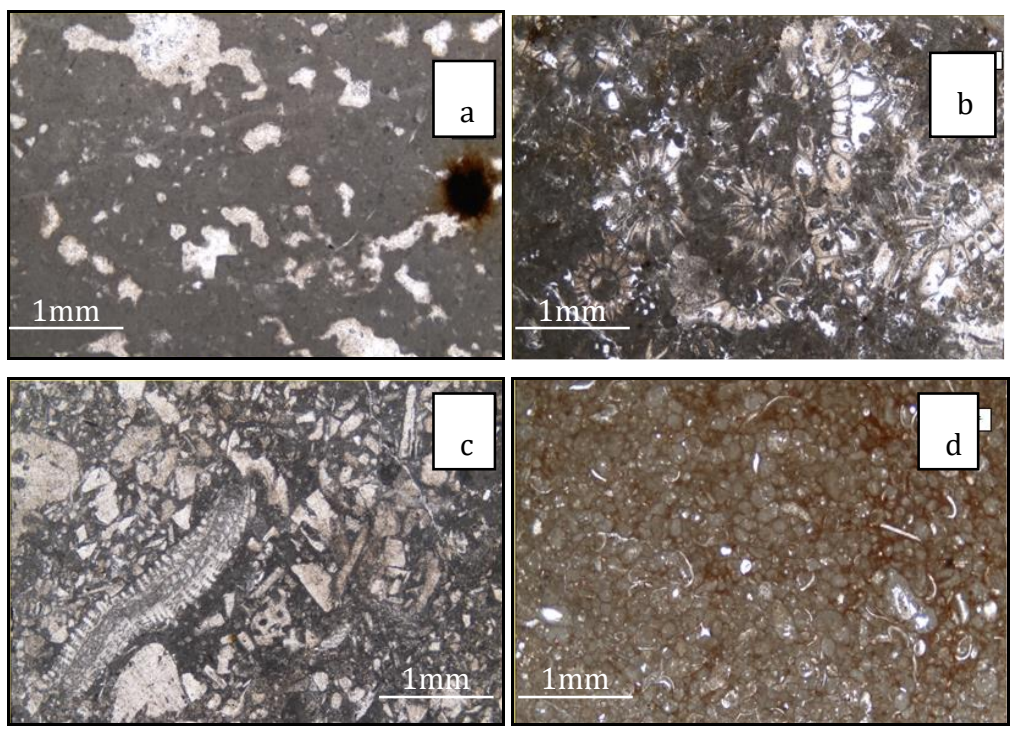

Şekil 9. Çambeleni kireçtașının en alt seviyelerine ait dismikritler (a), alt-orta kesimlerine ait yoğun algli (Calpionella jurassica) biyomikritler (b), bu kireçtaşlarının en üstüne ait rudistli kesimin Orbitodes cf. apiculatus'lu istiflenmiş biyosparitleri c) ve pelajik mikrofasiyeslere geçişi gösteren ince bivalv kavkılı biyomikritlerin (d) mikro fotoğrafları.

Cihandere formasyonunun dolomitlerinde (Dibekli dolomit üyesi) yaş verebilecek tanıtman bir forma rastlanamamışken Koç vd. [10] bu üyenin içindeki çok ince dolomitik kireçtaşı tabakalarında Jura'yı temsil eden bazı foraminifer ve alglere rastlamışlardır. Çambeleni üyesine karşılık gelen kalın kireçtaşı istifinin alt kesimlerde bivalvlerden Litotis sp. (Şekil, 8b) bulunmuşken, üyenin orta seviyelerinde de; Kurnubia palastiniensis, Kurnubia jurassica,
Opthalmidium sp., Pfenderia sp., Nautiloculina $s p$., Salpingoporella sp., Clipeina jurassica, Clipeina sp. Textularia sp. (SSekil, 9a, b) gibi foram ve alglere rastlanarak üyenin orta seviyelerinin Geç Jura- Erken Kretase'de çökeldiği düșünülmüștür. Çambeleni üyesinin rudistli seviyelerindeki Orbitoides cf. apiculatus, Orbitoides sp. (Şekil 9c,) formları ise Cihandere formasyonunun üst seviyelerinin Geç Senoniyen'e kadar çıtığını gösterir. Çambeleni istifinin en üst 
tabakalarında ayrıca mikritik fasiyesler içinde ince pelesipod kavkıları da bulunmaktadır (Șekil, 9d). Tümüyle sığ karbonat șelfi çökelleri olan Cihandere biriminin dolomitleri, başlangıçta iklimin sıcak ve platformun lagünlü olabileceğini düşündürürken; orta-üst seviyelere ait çoğu mikritik fasiyesler, düşük enerjili karbonat sığlıklarını işarettir. Aynı düzeyde görülen intrasparitler ise enejinin yer yer yükseldiğini belgeler. Cihandere formasyonu, Wilson'nun[22] sınırlanmıș platform karbonatlarına karşılıktır. Ancak Cihandere istifinin en üst tabakalarındaki ince bivalv kavkılı mikritler (Şekil 9d), Senoniyen sonlarında çökelmenin açık şelfe doğru kaydığını gösterir. Ermenek-Mut-Silifke dolaylarındaki Gedikdağı ve Çambaşıtepe formasyonları $[4,5,19]$ ve Aydıncık-Bozyazı yöresindeki Cehennemdere formasyonu [10], Cihandere karbonatlariyla tektonostratigrafi-ortam ve fosil içerikleri açısından deneștirilebilir.

\subsection{Hasanclk formasyonu (Kh)}

Çambeleni kireçtaşı üyesini uyumlu olarak örten, alacalı renkli şeyl-marn ara katkılı çörtlü kireçtaşları, Hasancık formasyonu olarak haritalanmıștır (Şekil 1, 2). Birim adı, Koç ve diğ. [10] tarafından kullanılmıştır. Birim inceleme alanında Hasancık güneyi ile Karaseki batısındaki grabenin kenar faylarının düşen bloklarında, dar-ince mostralar halinde yüzeyler (Şekil 1, 10). Hasancık formasyonu gri renkli, ince-orta katmanl, bol eklemli, seyrek çört yumrulu kireçtaşları ile başlar. İstif içinde gri, yeşilimsi gri, koyu sarı, pembemsi ve yumrumercek-kama șekilli çörtler, üste doğru giderek artar. Sıkışık kıvrımlı, yoğun eklemli plaket kireçtaşları, yukarıya doğru yeşilimsibej ve gül kurusu renkli killi kireçtaşı, marn ve şeyl seviyeleri de kapsar. Hasancık formasyonunun en üst seviyeleri; kırıntılı kireçtaşı, kumtaşı, şeyl, marn içeriklidir. Cihandere formasyonunu tedrici geçișliuyumlu bir dokanakla örten Hasancık birimi atmosfere açık olup, harita alanında Mut formasyonuyla dokanağı bulunmaz (Şekil 1, 10). Hasancık biriminin kalınlığı, çalışma alanında en çok 200 m'yi bulurken, üst sınırının aşınmalı olmasından ötürü, birimin kalınlığı mostralarda yer yer 50 m'ye kadar düșer. Hasanclk formasyonunun alt seviyesinde Globotruncana sp., Heterohelix sp., Rugoglobigerina sp., Hedbergella sp., Radiolaria sp. gibi pelajik mikrofaunalar görülmüşken, üst seviyelerde; Globotruncana linneiana, G. arca, G. bulloides, $G$. stuartiformis, Globotruncanita stuarti, Rosita fornicata türlerine rastlanmış ve birime Maastrihtiyen yaşı verilmiştir. Hasancık formasyonunun pelajik foram ve Radiolaria içerikli, çörtlü-killi mikritleri, düşük enerjili açık şelf koşullarını düşündürürken, üst düzeyledeki killi kireçtaşı ve marnlarla ardalanan şeyl ve kalkarenitler, çökel alanının yüksek enerjili türbiditik bir havzaya kaydığını gösterir. Hasancık formasyonu, Karaman batısındaki Pusala grubunun üst düzeyleri [16] ve Mersin kuzeyindeki Arslanköy ve Yavca formasyonları $[3,10]$ ile benzer litolojik ve stratigrafik özellikler sergiler.

\subsection{Mut formasyonu (Tm)}

Paleozoyik-Mesozoyik temel üzerinde açısal uyumsuzlukla duran, fosilli kireçtaşı ve killi kireçtaşı yapılışlı Alt Miyosen istifi, Mut formasyonunu oluşturur. Birim adı Gedik vd. [4]'den alınmıștır. Mut formasyonu inceleme alanının kuzeyinde Bozlu Tepe ve Kaya Mahallesi'nin doğusunda yüzeyler (Şekil 1). Mut formasyonu kirli beyaz-krem renkli, kalın-çok kalın tabakalı, bol makro-mikro fosilli (bivalv, mercan, ekinid ostrakod, alg ve foram) kireçtaşlarından yapılmıștır. $\mathrm{Bu}$ kireçtaşlarına üst kesimlerde killi kireçtaşımarn ara tabakaları da eșlik eder. Kireçtaşlarının üst yüzeylerinde çok yoğun lapya, dolin yapıları gözlenir. Formasyondan yapılmıș ince kesitlerde, mikritik ve sparitik örneklerin bir çoğunun bol fosilli biyolitit (bağlamtaşı) olduğu göze çarpar. Üst Permiyen ve Jura-Kretase kayalarını açılı uyumsuzlukla örten Mut formasyonu, çalıșma sahasında atmosfere açıktır. Ancak kuzeyde Gülnar civarlarında üzerine uyumlulukla Langhiyen-Serravaliyen yașta pelajik Köselerli formasyonu gelir [4, 23]. Mut biriminin incelenen bölgedeki kalınlığı 150-200 m kadardır (Şekil 1, 2). Mut formasyonunda; Archaeolithothamnium sp., Planorbulina sp., Peneroplis sp., Operculina sp., Elphidium sp., Amphistegina sp. gibi foramlar, Lithoporella sp., Lithothamnium sp., cinsi algler, ekinidlerden Clipeaster $s p$. ve bivalvlerden Ostrea $s p$. görülmüş ve formasyona Burdigaliyen yașı verilmiștir. Mut formasyonu temel üzerine transgresyon 
yapan bir denizde çökelmeye başlamıștır. Çok bol makro ve mikro fosil içeriği, bol oksijenli-sığ-sıcak bir denizi gösterirken, mikritik ve sparitik mikrofasiyeslerin birlikteliği, su enerjisinin bazan düşük, bazanda yüksek olduğuna delildir. Mut formasyonunun bazı seviyeleri resif ardını, bazı seviyeleri resif çekirdeğini, en üstteki killi kireçtaşı ve marn ara katkılı bölümler ise resif ilerisini gösterir. Mut formasyonu, Orta Toroslar'da aynı adlı birimlerle [4, 3] ve Karaisalı kireçtaşı [23] ile korelatiftir.

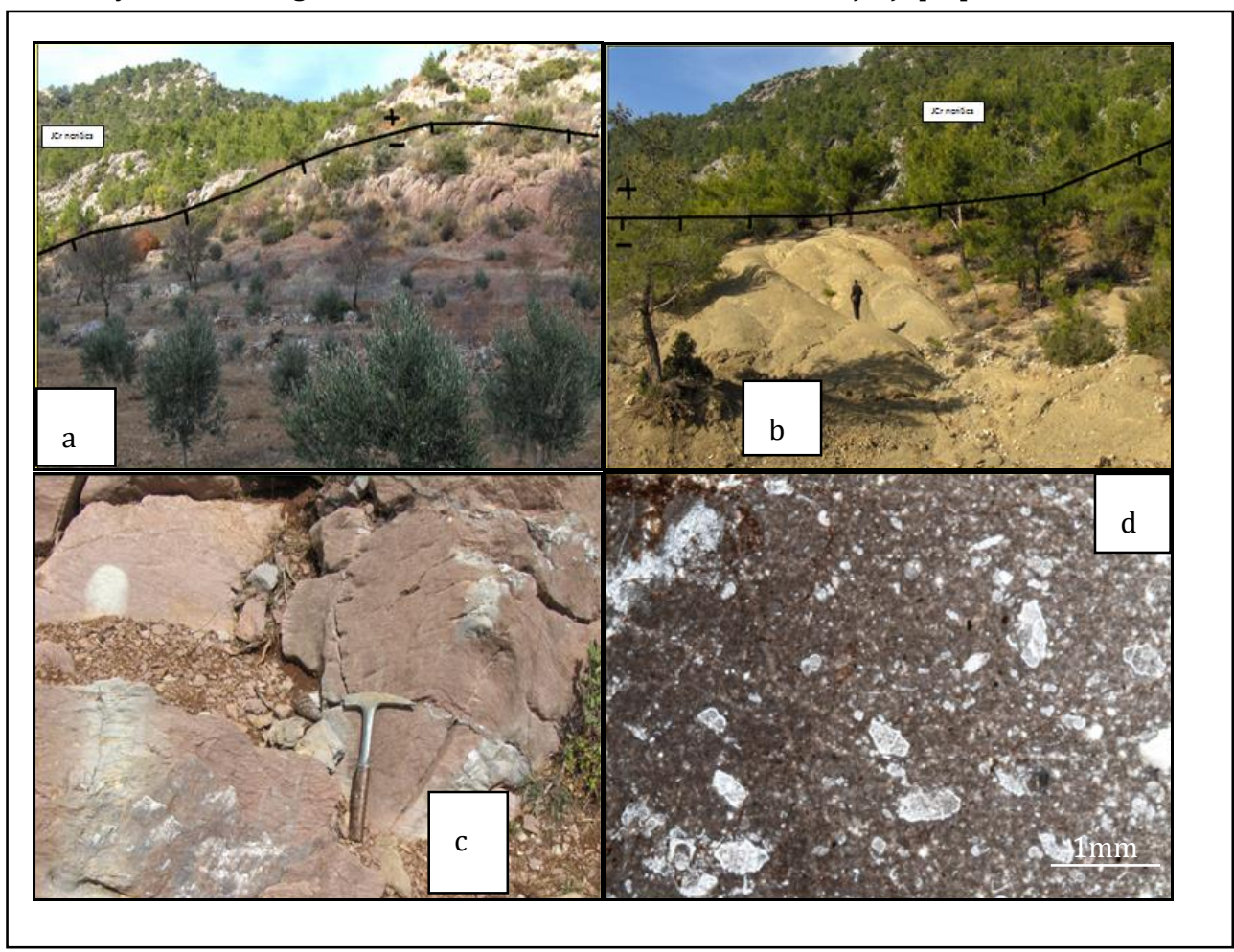

Şekil 10. Cihandere-Hasancık formasyonlarının gravite faylı dokanak ilişkileri (a, b), Hasancık formasyonunun bordo-kahvemsi renkli marn-killi kireçtaşı-şeyl ve kumtaşları (a-c) ile Globotruncana'lı istiflenmiş az killi biyomikritler (d).

\subsubsection{Alüvyon (Qa)}

Bölgedeki dere yataklarında çakıl-kumçamurdan oluşan ve kalınlığı 20 m'ye kadar varabilen alüvyonlar birikmişlerdir. Alüvyon birimleri, alttaki formasyonlar üzerinde uyumsuz olarak evrimini Kuvaterner'den beri sürdürmektedirler.

\section{SONUÇLAR}

1-) Aladă̆ Birliği veya Hadim napı, Orta Toros kuşağının en üst allokton dilimidir ve bölgede Üst Devoniyen'den Üst Kretase'ye kadar stratigrafi birimleri kapsar. Aladağ Birliğinin Orta Triyas serileri hariç tamamı, Aydıncık çevresinde görülmektedir. Bölgedeki Üst Devoniyen-Karbonifer ve Alt Permiyen istifleri, (Asarlıkyaylası, Yarıcak ve
Arpalık formasyonları) birbirinin uyumlu devamı şeklinde olup, resifli-duraylı sığ deniz șelfi sedimentlerinden yapılmışlardır.

2-) Yöredeki Üst Permiyen istiflerinin (Kuşakdağı formasyonu), Alt Permiyen ile uyumluluğu, yazar da dahil tüm yer bilimcilerin geçmișteki genel kanısıdır. Ancak Üst Permiyen'in her yerde yaklașık 20-30 m'lik klavuz bir kuvarsit seviyesi ile bașlaması (Şekil,2) ve alttaki istiflerde eksikliklerin görülmesi, bu görüşü kuşkulu hale getirmiștir. Aydıncık-Bozyazı kara yolu üzerinde, Soğuksu faylı karst kaynağının DGD'sundaki yol yarmasında, Üst Devoniyen üzerinde direkt Üst Permiyen'in varlığı (Şekil 1) ve harita alan dışında Aydıncık- Gülnar yolundaki Sele Yokuşu'nda, Üst Devoniyen 
birimleri üzerinde yine Üst Permiyen birimlerinin izlenmesi, Üst Permiyen'in tabanındaki bir uyumsuzluğu gösterir. Yine Bozyazı'nın Kök Mahallesi civarında da, eksik Karbonifer istiflerinin üzerine doğrudan Üst Permiyen birimleri oturmaktadır [20]. Dolayısıyla bu gözlemler Geç Permiyen öncesinde, Bozyazı-Aydıncık- bölgesinin, belirgin bir orojenik etkinlik olmasa bile deniz seviyesi üzerinde kalarak aşınmış olduğunu ortaya koymaktadır.

3-) Geç Permiyen'den Orta Triyas başlarına kadar denizel istiflerin görülebildiği Aydıncık yöresinde, gelgit üstü-karıșık kıyı, lagünlü sığ şelf, gelgit altı durgun ve çalkantılı karbonat șelfi fasiyesleri șekillenmiștir. Orta Triyas sırasında derinleşen ve yeğin orojenik aktivite kazanan bu çökel alanında oluşan fliș istifleri , Orta Triyas sonlarından itibaren, kıvrımlanıp yükselerek bir orojen haline gelmiștir [19, 20, 21]. Erken Liyas başlarında, Erken Kimmeriyen orojenik fazı ile önemli bir dağ kuşağı haline gelen bölge, hızla așındırılmıștır. Liyas-Dogger sürecinde, alüvyal yelpaze-akarsu fasiyeslerinde, çakıltașı egemen kızıl renkli konglomerakumtaşı-çamurtaşı yapılışlı ve 100-150 m kalınlıklı Çamiçi formasyonu çökelmiştir. Önceki çalışmalarda Geç Triyas olarak yaşlandırılan ve Aydıncık-Silifke arasında Murtçukuru formasyonu (Çamiçi ve Dedebeleni formasyonlarının ikisine birden karşılıktır) olarak bilinen bu birim ile Göztaşı formasyonu arasındaki açllı uyumsuzluk Toroslar'da izleri olan Erken Kimmeriyen dağ olușumuyla ilișkilidir ve Göktepe ve Güvenç'in de [6] önerdiği gibi bu birim, Jura'da oluşmuştur. Karasal Çamiçi formasyonu ve üzerinde uyumlu olan yarı karasal Dedebeleni formasyonu ile Geç JuraKretase yașlı sığ șelf karbonatları (Cihandere formasyonu), stratigrafik-sedimantolojik ve yapısal açıdan biri birleriyle uyum içinde olan, sürekli tortul istifler (Şekil 1, 2) olarak yorumlanmışlardır.

4-) Aladağ Birliği veya Hadim napı istiflerinin Alt Kretase'ye kadar çıktığı, yazar ve Orta Toros Kuşağında çalışmış deneyimli jeologların genel kanısı iken $[3,4,11,13,14$, 15, 18, 19, 20], bu çalışma ile Aladağ Birliğinin Aydıncık yöresinde Geç Kretase sonuna kadar istifler sunduğu kesindir. Cambeleni üyesinin en üst seviyelerindeki Üst Senoniyen'i gösteren orbitoidli ve rudistli neritik kireçtaşları ve Maastrihtiyen'i gösteren Globotruncana'lı pelajik istifler içeren Hasancık formasyonu, Aydıncık civarında Mesozoyik istiflerinin Kretase sonuna eriștiğinin kanıdır.

\section{KATKI BELİRTME}

Yazar makale verilerinin sağlandı̆̆ 11201065 nolu SÜAF projesine destek veren Selçuk Üniversitesi BAP Koordinatörlüğüne, Paleozoyik foraminifer ve alglerini tanımlayan uzman paleontologlar Prof.Dr. Yavuz OKAN (Ankara Üniv.), Prof.Dr. Cengiz OKUYUCU (Selçuk Üniversitesi) ve Hüseyin YAKAR (TPAO)'a, Mesozoyik fosillerini tayin eden Prof.Dr. Sacit ÖZER, Doç.Dr. Bilal SARI ile Yrd. Doç.Dr. İsmail IȘINTEK'e (Dokuz Eylül Üniversitesi) ve Kemal ERDOĞAN'a (MTA) ayrı ayrı teşekkür eder.

\section{KAYNAKLAR}

[1] Baydar, O., Erdoğan , B.,Kengil, R., Kaynar, A.ve Selim, M., 1970, Uçarı-Teniste-KaşyaylaSazak-Bozyazı ve Anamur arasındaki bölgenin jeolojisi; MTA Rap., No: 82, Ankara (yayınlanmamış).

[2] Blumenthal, M.,1944, Bozkır güneyinde Toros sıradağlarının serisi ve yapısı; İ.Ü.F.F. Mec., seri : B, 9., 95-125.

[3] Demirtaşlı, E., 1984, stratigraphy and tectonics of the area between Silifke and Anamur, Central Taurus Mountains; International Symposium on the Geology of the Taurus Belt, 101-118, Ankara-Turkey.

[4] Gedik, A., Birgili, Ş., Yılmaz, H. ve Yoldaş, R.,1979, Mut-Ermenek-Silifke yöresinin jeolojisi ve petrol olanakları; Türkiye Jeoloji Kur. Bült., 22-1, 7-26.

[5] Gökten, E., 1976, Silifke yöresinin temel kaya birimleri ve Miyosen stratigrafisi; Türkiye Jeol. Kur. Bült, 19-2, 103-117.

[6] Göktepe, G. ve Güvenç, T., 1997, Hadim napı Üst Permiyen stratigrafisi ve paleontolojisi; Çukurova Üniv.'de Jeoloji Mühendisliği Eğitiminin 20. Yılı Simp., bildiri özleri, 213-214.

[7] Gürçay, B., 2000, Aydıncık (İçel) batısının jeolojisi; Cumhuriyetin 75. Yıldönümü yerbilimleri ve Madencilik Kongresi kitapçı̆̆ı, 93-105, MTA- Ankara. 
[8] Güvenç, T., 1965, Etude stratiraphique et micropaleontologique du Carbonifere et du Permien des Taurus Occidentaux dans l'arrivere-pays D'Alanya (Turquie) 4 volume, These de Doct., Univ. Paris.

[9] Irwin, M. L. 1965, General theory of epeiric clear water sedimentation; Amer. Assoc. Petroleum Geologists, bull. v. 49, 445459.

[10] Koç, H., Ünlügenç, U. C., Özer, E., 2005, Aydıncık-Bozyazı (Mersin) arasının tektonostratigrafik incelemesi, Orta Toroslar, Türkiye; Türkiye Jeoloji Bült. cilt 48, sayı 1, 125.

[11] Kușçu, M. 1983, Göktepe (Ermenek) yöresinin jeolojisi ve $\mathrm{Pb}-\mathrm{Zn}$ yatakları; Selçuk Üniv. Müh.-Mim. Fak. doktora tezi (yayınlanmamış), 181.

[12] Okuyucu, C. ve Güvenç, T. 1997, Hadim Napı'nda Karbonifer-Permiyen geçişi, Girvanella kireçtaşı oluşum paleontolojisi; Geosound Yer bilimleri Derg., 30/1, 463-473.

[13] Özer, E., Koç, H., Zorlu, K., ve Altuncu, A., 2003, Anamur (Mersin) kuzeydoğusunun tektono-stratigrafik özellikleri; Geosound Yerbilimleri Derg., sayı: 43, 183-194.

[14] Özgül, N., 1976, Toroslar'ın bazı temel jeoloji özellikleri; Türkiye Jeoloji Kur. Bült. 19, 65-78.

[15] Özgül, N., 1984, Stratigraphy and tectonic evolution of the Central Taurides; Intern. Symp. of the Geology of Taurus Belt, 77-90, Ankara.

[16] Özgül, N., 1997, Bozkır-Hadim-Taşkent (Orta Toroslar'ın kuzey kesimi) dolayında yer alan tektono-stratigrafik birliklerin stratigrafisi; MTA Derg.,119, 113-174.

[17] Selley, R. C., 1976, An introduction to sedimentology; Acad. Pres, London.

[18] Turan, A., 1990, Toroslar'da Hadim(Konya) ve güneybatısının jeolojisi, stratigrafisi ve tektonik gelişimi; Selçuk Üniv. Fen Bil. Ens., doktora tezi (yayınlanmamış), 229.

[19] Turan, A., 1998, Göksu Vadisi boyunca yüzeyleyen Miyosen öncesi tektonostratigrafik birliklerin stratigrafisi: Silifke batısı (İçel); Geosound Yerbilimleri derg., 30/2, 855-874.
[20] Turan, A., 2007, Bozyazı (Mersin) ve kuzey kesiminin tektono-stratigrafisi; Selçuk Üniv. Müh.-Mim. Fak. Derg., cilt: 23, sayı: 1-2, 97-115.

[21] Turan, A., Kurtman, F., Seymen, İ., 2007, Hadim bölgesinin paleotektonik dönem jeolojik evrimi; Selçuk Üniv. Müh.-Mim. Fak. Derg., cilt: 23, sayı: 1-2, 115-130.

[22] Wilson, J. L., 1975, Carbonate facies in geologic history; Springer Verlag, Berlin, Newyork, 447.

[23] Yetiș, C., 2002, Abanoz Yayla (AnamurMersin) dolayı Karaisalı kireçtașı sedimanter petrografik özellikleri; Çukurova Üniv. Müh.Mim. Fak. Derg., 17/1-2, 117-134. 